УДК 633.111:632.4:631.8, DOI 10.31210/visnyk2018.02.11

(C) 2018

Тищенко М. В., кандидат сільськогосподарських наук,

Смірних В. М., кандидат сільськогосподарських наук

Веселоподільська дослідно-селекційна станція

Інституту біоенергетичних культур і цукрових буряків НААН України

Філоненко С. В., кандидат сільськогосподарських наук,

Ляшенко В. В., кандидат сільськогосподарських наук

Полтавська державна аграрна академія

\title{
УРАЖЕННЯ РОСЛИН ПШЕНИЦІ ОЗИМОЇ КОРЕНЕВИМИ ГНИЛЯМИ ЗАЛЕЖНО ВІД АГРОТЕХНІЧНИХ ЗАХОДІВ
}

\section{Рецензент - доктор сільськогосподарських наук, професор П. В. Писаренко}

У результаті польових досліджень було встановлено вплив попередників, системи удобрення і способів основного обробітку трунту на ураження рослин пшениці озимої кореневими гнилями в короткоротаиійних сівозмінах зони недостатнього зволоження. Найбільше уражених рослин пшениці озимої кореневими гнилями виявилось в зернопросапній сівозміні, де попередником була сама пшениия, а також в зернопаропросапній сівозміні, де попередником був чорний пар. Найменше уражених кореневими гнилями рослин пиениці озимої (15,3-20,0\%) за найнижчої інтенсивності розвитку хвороби (5,8-7,3\%) спостерігали після кукурудзи на силос. Проведення поверхневого обробітку трунту на глибину 10-12 cм під зернові культури, в тім числі й під пиеницю озиму, на фоні 6,25 m гною $+N_{33,8} P_{45,0} K_{33,8}+$ солома + гичка в просапній сівозміні після кукурудзи на силос спричинило найбільше ураження рослин пшениці кореневими гнилями $(24,4 \%)$ з підвищенням інтенсивності розвитку хвороби до величини 10,5\%. Проведення оранки під усі культури в просапній сівозміні за внесення за ротацію сівозміни з розрахунку на 1 га ріллі 6,25 $\mathrm{m}$ гною $+N_{33,8} P_{45,0} K_{33,8}+$ солома + гичка забезпечило найвищу урожайність зерна пшениці озимої- 4,39 m/2а.

Ключові слова: пшениия озима, кореневі гнилі, обробіток трунту, сівозміна, система удобрення, поширення хвороби, ураження рослин.

Постановка проблеми. Пшениця озима за своїм значенням займає в Україні провідне місце серед усіх зернових культур. Виробництво іiі зерна вважається одним із стратегічних напрямів зміцнення економіки держави. Проте одним із факторів, що суттєво знижують її врожайність та якість зерна, є хвороби. Відомо, що втрати валового збору зерна від хвороб щорічно становлять 20-30\%, а в епіфітотійні роки - до $50 \%$ [7]. Тому знання особливостей розвитку хвороб на пшениці озимій, моніторинг видового складу патогенів, рівня інфікованості іiі зерна грибами, ступеня забрудненості мікотоксинами потребує постійного контролю за відповідними чинниками 3 метою наступного проведення відповідних захисних заходів щодо культури.

Загальновідомо, що у процесі еволюції та вирощування пшениці до неї пристосувалося багато збудників хвороб, серед яких домінуюче місце належить саме грибним мікроорганізмам. На посівах пшениці озимої ураження рослин і прояв захворювання спостерігаються протягом усього періоду інтенсивного розвитку та формування елементів продуктивності рослин [4].

Серед усіх збудників хвороб, що уражують рослини пшениці озимої у ранні фази розвитку, кореневі гнилі займають головну позицію. У цілому, кореневі гнилі пшениці озимої - поширений комплекс шкідливих захворювань. Залежно від збудників хвороби вирізняють звичайну, фузаріозну, офіобольозну, церкоспорельозну і ризоктоніозну кореневі гнилі. У певній кліматичній зоні, як правило, переважає один тип ураження, що є найшкідливішим. В умовах України найчастіше трапляються фузаріозна i звичайна кореневі гнилі [6].

На поширення, інтенсивність розвитку та ступінь ураження рослин пшениці озимої кореневими гнилями впливає багато чинників, серед яких агротехнічні заходи займають чільне місце. Саме тому дослідження впливу добрив, сівозмін і способів основного обробітку грунту на інтенсивність ураження рослин пшениці озимої кореневими гнилями в зоні недостатнього зволоження є важливими і актуальними.

Аналіз основних досліджень і публікацій, у яких започатковано розв'язання проблеми. Коренева гниль - хвороба коренів і прикореневої частини стебел пшениці озимої, яка викликається одним видом або комплексом видів напівпаразитних грибів (фузаріум, гельмінтоспоріум, церкоспорелла й інші). 


\section{СІЛЬСЬКЕ ГОСПОДАРСТВО. РОСЛИННИЦТВО}

Хвороба зовні відмічається у вигляді побуріння коренів, підземного міжвузля, вузла кущіння, основи стебла і нижніх листків. Уражені корені і підземне міжвузля стають крихкими і обламуються при висмикуванні рослин із грунту. Вузли кущіння робляться трухлявими і втрачають свою міцність. Захворювання впливає на стан рослин протягом всієї вегетації. Воно викликає загибель сходів, відставання в рості, щуплість колосу в уражених рослин або повне відмирання продуктивних стебел. Сильне ураження пшениці кореневими гнилями на значній території або в окремих місцях спостерігається в роки, несприятливі для іiі розвитку, а також в разі порушення агротехніки. Шкодочинність виявляється в зниженні кількості та якості врожаю. Розмір шкоди визначається умовами вирощування пшениці озимої i паразитичними властивостями патогенів. Тому шкодочинність хвороб змінюється за роками i природно-господарськими зонами [2].

В основних районах вирощування пшениці озимої частіше збудниками кореневих гнилей $є$ гриби із роду Fusarium (Fusarium avenaceum, Fusarium qraminearum та інші). Дослідженнями встановлено, що в умовах достатнього забезпечення вологою (60-80\% повної вологоємності грунту) рослини менше піддаються захворюванню. За дефіциту або за різких коливань вмісту вологи в грунті, а також в разі утворення кірки на поверхні грунту й за інших несприятливих факторів, які послаблюють рослини, спостерігається значний розвиток кореневих гнилей, збільшується кількість загиблих рослин, а із тих, що збереглися на час збирання, відсоток уражених зростає вдвічі. За ураження 5-10\% рослин пшениці озимої втрати врожаю можуть досягти 3,5-7 \% [5].

Мета досліджень полягала у встановленні впливу добрив, сівозмін і способів основного обробітку грунту на ураження рослин пшениці озимої кореневими гнилями.

Завдання досліджень:

- дослідити вплив попередників і системи удобрення на ураженість рослин пшениці озимої кореневими гнилями;

- дослідити i проаналізувати комплексний вплив способів основного обробітку грунту і системи удобрення на інтенсивність ураження рослин пшениці озимої кореневими гнилями та іiі зернову продуктивність;

- вивчити вплив способів основного обробітку грунту в сівозміні і системи удобрення культур на поширення кореневих гнилей пшениці озимої та їі врожайність.

Матеріали і методи досліджень. Польові дослідження проводили в стаціонарному досліді
Веселоподільської дослідно-селекційної станції Інституту біоенергетичних культур i цукрових буряків Національної академії аграрних наук України (Семенівський район, Полтавська область) упродовж 2012-2016 pp. У результаті досліджень передбачалось встановити вплив короткоротаційних сівозмін, добрив і способів основного обробітку грунту на ураження рослин пшениці озимої кореневими гнилями.

Грунт дослідного поля - чорнозем типовий слабкосолонцюватий малогумусний середньосуглинковий, що характеризується такими агрохімічними показниками орного шару: $\mathrm{pH}$ сольової витяжки - 7,2-7,7; ємність поглинання коливається в межах 37-39 мг-екв. на 100 г грунту; гумус за Тюріним - 4,5-4,7\%, забезпеченість рухомим фосфором та обмінним калієм (за Мачигіним) складає 50,9-64,5 i 143,2-153,2 мг/кг грунту відповідно.

Територія станції знаходиться в зоні недостатнього зволоження Лівобережного Лісостепу, де середня багаторічна кількість опадів, за даними метеостанції Веселий Поділ, протягом року становить 511 мм, а за вегетаційний період - 326 мм. Клімат - помірно-континентальний 3 недостатнім зволоженням. Середньобагаторічна середньорічна температура повітря складає $+7,7{ }^{0} \mathrm{C}$, сума активних температур $\left(>+5{ }^{0} \mathrm{C}\right)-2030{ }^{\circ} \mathrm{C}$, сума ефективних температур $\left(>+10{ }^{\circ} \mathrm{C}\right)-1275{ }^{\circ} \mathrm{C}$.

Агрометеорологічні умови за роки проведення досліджень характеризувались деякими відхиленнями від середніх багаторічних показників, але в цілому вони були сприятливими для вирощування пшениці озимої й інших сільськогосподарських культур.

Чергування культур у короткоротаційних сівозмінах було наступним: плодозмінна сівозміна - еспарцет, пшениця озима, цукрові буряки, ячмінь $з$ підсівом еспарцету; просапна сівозміна кукурудза на силос, пшениця озима, цукрові буряки, ячмінь; зернопаропросапна сівозміна чорний пар, пшениця озима, цукрові буряки, ячмінь; зернопросапна сівозміна - пшениця озима, пшениця озима, цукрові буряки, соя.

Система удобрення в короткоротаційних сівозмінах передбачала внесення на 1 га ріллі сівозміни: 6,25 т гною $+\mathrm{N}_{33,8} \mathrm{P}_{45,0} \mathrm{~K}_{33,8}$ без соломи, без гички (варіанти 4, 10, 16, 22, 28, 34, 40, 46, 52, 58, 64, 70); 6,25 т гною $+\mathrm{N}_{33,8} \mathrm{P}_{45,0} \mathrm{~K}_{33,8}+$ солома + гичка (варіанти 5, 11, 17, 23, 29, 35, 41, 47, 53, 59, 65, 71). На контролі культури у сівозмінах вирощували без добрив, без соломи, без гички (варіанти 3, 9, 15, 21, 27, 33, 39, 45, 51, 57, 63, 69).

Схема стаціонарного досліду включала наступні способи основного обробітку грунту під 


\section{СІЛЬСЬКЕ ГОСПОДАРСТВО. РОСЛИННИЦТВО}

культури у сівозмінах: контроль - оранка на глибину 30-32 см під цукрові буряки, оранка на глибину 20-22 см під кукурудзу на силос, оранка на глибину 20-22 см під зернові культури, в тім числі під пшеницю озиму (варіанти 9, 10, 11, 27, $28,29,63,64,65)$; плоскорізний обробіток грунту під усі культури, в тім числі й під пшеницю озиму на глибину 20-22 см (варіанти 3, 4, 5, 57, $58,59)$; поверхневий обробіток грунту на глибину 10-12 см під зернові культури, в тім числі й під пшеницю озиму (варіанти 21, 22, 23); культивацію на глибину 8-10 см під пшеницю озиму (варіанти 45, 46, 47); комбінований обробіток грунту - оранка на глибину 30-32 см під цукрові буряки, плоскорізний обробіток грунту під зернові культури, в тім числі й під пшеницю озиму на глибину 20-22 см (варіанти 15, 16, 17, 69, 70, 71).

Сівозміни стаціонарного досліду розміщені на 4-х полях, площа посівної ділянки - 182 м², об-

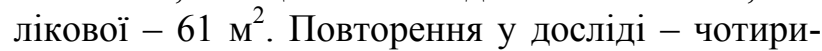
разове, розміщення ділянок - систематичне.

Ураження рослин пшениці озимої кореневими гнилями досліджували впродовж 2012-2016 рр. Перед сівбою насіння пшениці озимої протруювали «Раксілом Ультра», $12 \%$ т.к.с. $(0,25$ л/т). Ураженість рослин пшениці озимої кореневими гнилями визначали за методикою Всесоюзного науково-дослідного інституту захисту рослин.

Основними збудниками кореневих гнилей пшениці озимої в умовах станції були гриби родів Fusarium та Bipolaris sorokiniana, що становили $73 \%$ усіх грибів, виділених із хворих рослин.

Технологія вирощування культур у досліді загальноприйнята для зони недостатнього зволоження. Оранку під цукрові буряки і зернові культури, в тому числі й під пшеницю озиму, проводили плугом «ПН-3-35»; плоскорізне безполицеве розпушування під усі культури виконували стійками «Параплау».

На дослідних ділянках висівали насіння районованих сортів та гібридів відповідних культур: гібрид цукрових буряків - Булава, сорт пшениці озимої - Єсенія, сорт ячменю - Геліос, сорт еспарцету - Піщаний 1251, гібрид кукурудзи на силос - Солонянський, сорт сої - Алмаз. Облік урожайності пшениці озимої проводили поділянково-суцільним зважуванням.

Дослідження проводили відповідно до методики польового досліду [1] і виконували згідно 3 методичними вказівками ІБКіЦБ [3].

Результати досліджень. Проведені нами п’ятирічні дослідження показали, що найменше уражених кореневими гнилями рослин пшениці озимої (15,3-20,0 \%) за найнижчої інтенсивності розвитку хвороби (5,8-7,3\%) було відмічено після кукурудзи на силос, що слугувала попередником (табл. 1). Після інших попередників ураження рослин пшениці озимої кореневими гнилями істотно зростало, причому як на неудобреному фоні без добрив, без соломи, без гички (варіанти 9, 45, 63), так і на фоні 6,25 т гною + $\mathrm{N}_{33,8} \mathrm{P}_{45,0} \mathrm{~K}_{33,8}$ без соломи, без гички (варіанти 10, $46,64)$ та на фоні 6,25 т гною $+\mathrm{N}_{33,8} \mathrm{P}_{45,0} \mathrm{~K}_{33,8}+$ солома + гичка (варіанти $11,47,65)$.

Значним ураження рослин виявилось у посівах пшениці озимої, що йшла по пшениці в зернопросапній сівозміні, а також після чорного пару в зернопаропросапній сівозміні, де було уражено $23,5-33,4 \%$ та $22,0-26,4 \%$ рослин культури, а інтенсивність розвитку хвороби становила 9,5-12,9\% та 8,4-10,2 \% відповідно.

Аналіз впливу ураження рослин пшениці озимої кореневими гнилями залежно від внесення добрив показав, що в посівах цієї культури після еспарцету і кукурудзи на силос застосування за ротацію сівозміни з розрахунку на 1 га ріллі 6,25 т гною $+\mathrm{N}_{33,8} \mathrm{P}_{45,0} \mathrm{~K}_{33,8}$ без соломи, без гички (варіанти 10 і 28) та 6,25 т гною $+\mathrm{N}_{33,8} \mathrm{P}_{45,0} \mathrm{~K}_{33,8}+$ coлома + гичка (варіанти 11 і 29) викликало збільшення ураження рослин пшениці кореневими гнилями до рівня 31,4 i $15,3 \%$ та 31,8 i 20,0\% відповідно, а також підвищення інтенсивності розвитку хвороби до рівня 12,5 і 5,8 \% та 10,8 i 7,3 \% відповідно. На ділянках контрольних варіантів, де не вносили ніяких добрив, ні соломи, ні гички (варіанти 9 і 27), поширення хвороби й інтенсивність іiі розвитку становили 17,3 і 15,6 \% та 6,9 і 6,0 \% відповідно.

Слід відмітити, що вирощування пшениці озимої після чорного пару за внесення за ротацію сівозміни з розрахунку на 1 га ріллі 6,25 т гною $+\mathrm{N}_{33,8} \mathrm{P}_{45,0} \mathrm{~K}_{33,8}$ без соломи, без гички (варіант 46) і 6,25 т гною $+\mathrm{N}_{33,8} \mathrm{P}_{45,0} \mathrm{~K}_{33,8}+$ солома + гичка (варіант 47) сприяло зменшенню кількості хворих рослин пшениці на 4,4 і 2,2 \% та зниженню інтенсивності розвитку хвороби на 1,8 і 0,6 \% відповідно порівняно 3 контролем без добрив, без соломи, без гички (варіант 45).

Найменша врожайність зерна пшениці озимої одержана із ділянок, на яких попередником була кукурудза на силос $(2,96$ т/га на неудобреному фоні без добрив, без соломи, без гички і 3,914,39 т/га на удобреному фоні) і сама пшениця (3,04 т/га на фоні без добрив, без соломи, без гички і 4,13-4,25 т/га на фоні з добривами). 


\section{1. Ураженість пшениці озимої кореневими гнилями та ї̈ врожайність залежно від попередників і внесення добрив (в середньому за 2012-2016 рр.)}

\begin{tabular}{|c|c|c|c|c|c|}
\hline \multirow{2}{*}{ Варіант } & \multirow{2}{*}{ Попередник } & \multirow{2}{*}{$\begin{array}{c}\text { Система удобрення } \\
\text { за ротацію сівозмі- } \\
\text { ни з розрахунку на } \\
1 \text { га ріллі } \\
\end{array}$} & \multicolumn{2}{|c|}{$\begin{array}{c}\text { Ураженість пшениці озимої } \\
\text { кореневими гнилями }\end{array}$} & \multirow{2}{*}{$\begin{array}{c}\text { Урожайність } \\
\text { пшениці } \\
\text { озимої, т/га }\end{array}$} \\
\hline & & & поширення, \% & $\begin{array}{l}\text { інтенсивність } \\
\text { розвитку, \% }\end{array}$ & \\
\hline 9 & \multirow{3}{*}{ Еспарцет } & $\begin{array}{c}\text { Без добрив, без } \\
\text { соломи, без гички }\end{array}$ & 17,3 & 6,9 & 4,44 \\
\hline 10 & & $\begin{array}{c}\text { 6,25 т гною + } \\
\mathrm{N}_{33,8} \mathrm{P}_{45,0} \mathrm{~K}_{33,8} \text { без } \\
\text { соломи, без гички }\end{array}$ & 31,4 & 12,5 & 4,66 \\
\hline 11 & & $\begin{array}{c}6,25 \text { т гною + } \\
\mathrm{N}_{33,8} \mathrm{P}_{45,0} \mathrm{~K}_{33,8}+ \\
\text { солома + гичка }\end{array}$ & 31,8 & 10,8 & 5,08 \\
\hline 27 & \multirow{3}{*}{$\begin{array}{l}\text { Кукурудза } \\
\text { на силос }\end{array}$} & $\begin{array}{l}\text { Без добрив, без } \\
\text { соломи, без гички }\end{array}$ & 15,6 & 6,0 & 2,96 \\
\hline 28 & & $\begin{array}{c}\text { 6,25 т гною + } \\
\mathrm{N}_{33,8} \mathrm{P}_{45,0} \mathrm{~K}_{33,8} \text { без } \\
\text { соломи, без гички } \\
\end{array}$ & 15,3 & 5,8 & 3,91 \\
\hline 29 & & $\begin{array}{c}6,25 \text { т гною + } \\
\mathrm{N}_{33,8} \mathrm{P}_{45,0} \mathrm{~K}_{33,8}+ \\
\text { солома + гичка }\end{array}$ & 20,0 & 7,3 & 4,39 \\
\hline 45 & \multirow{3}{*}{ Чорний пар } & $\begin{array}{c}\text { Без добрив, без } \\
\text { соломи, без гички }\end{array}$ & 26,4 & 10,2 & 5,66 \\
\hline 46 & & $\begin{array}{c}\text { 6,25 т гною + } \\
\mathrm{N}_{33,8} \mathrm{P}_{45,0} \mathrm{~K}_{33,8} \text { без } \\
\text { соломи, без гички }\end{array}$ & 22,0 & 8,4 & 6,32 \\
\hline 47 & & $\begin{array}{c}6,25 \text { т гною + } \\
\mathrm{N}_{33,8} \mathrm{P}_{45,0} \mathrm{~K}_{33,8}+ \\
\text { солома + гичка }\end{array}$ & 24,2 & 9,6 & 5,92 \\
\hline 63 & \multirow{3}{*}{$\begin{array}{c}\text { Пшениця ози- } \\
\text { ма }\end{array}$} & $\begin{array}{l}\text { Без добрив, без } \\
\text { соломи, без гички }\end{array}$ & 23,5 & 9,5 & 3,04 \\
\hline 64 & & $\begin{array}{c}\text { 6,25 т гною + } \\
\mathrm{N}_{33,8} \mathrm{P}_{45,0} \mathrm{~K}_{33,8} \text { без } \\
\text { соломи, без гички } \\
\end{array}$ & 27,2 & 11,5 & 4,13 \\
\hline 65 & & $\begin{array}{c}6,25 \text { т гною + } \\
\mathrm{N}_{33,8} \mathrm{P}_{45,0} \mathrm{~K}_{33,8}+ \\
\text { солома + гичка }\end{array}$ & 33,4 & 12,9 & 4,25 \\
\hline \multicolumn{3}{|c|}{ HIP $_{05}$ загальна } & 2,1 & 0,7 & 0,21 \\
\hline \multirow{2}{*}{\multicolumn{3}{|c|}{$\begin{array}{l}\text { HIP }_{05} \text { для ф-ра А (сівозміна) } \\
\text { HIP }_{05} \text { для ф-ра В (удобрення) }\end{array}$}} & 1,6 & 0,5 & 0,15 \\
\hline & & & 0,9 & 0,2 & 0,10 \\
\hline
\end{tabular}

Найбільшу врожайність зерна культури отримали після чорного пару: 5,66 т/га на неудобреному фоні без добрив, без соломи, без гички (варіант 45), 6,32 т/га на фоні 6,25 т гною + $\mathrm{N}_{33,8} \mathrm{P}_{45,0} \mathrm{~K}_{33,8}$ без соломи, без гички (варіант 46 ) $\mathrm{i}$ 5,92 т/га на фоні 6,25 т гною $+\mathrm{N}_{33,8} \mathrm{P}_{45,0} \mathrm{~K}_{33,8}+$ солома + гичка (варіант 47).

Досить висока зернова продуктивність пшениці озимої відмічена також і після еспарцету 4,44 т/га на фоні без добрив, без соломи, без гички (варіант 9), 4,66 т/га на фоні 6,25 т гною + $\mathrm{N}_{33,8} \mathrm{P}_{45,0} \mathrm{~K}_{33,8}$ без соломи, без гички (варіант 10) i
5,08 т/га на фоні 6,25 т гною $+\mathrm{N}_{33,8} \mathrm{P}_{45,0} \mathrm{~K}_{33,8}+$ солома + гичка (варіант 11).

Необхідно зазначити, що внесення за ротацію сівозміни в розрахунку на 1 га ріллі 6,25 т гною $+\mathrm{N}_{33,8} \mathrm{P}_{45,0} \mathrm{~K}_{33,8}$ без соломи, без гички (варіанти $10,28,46,64)$ і 6,25 т гною $+\mathrm{N}_{33,8} \mathrm{P}_{45,0} \mathrm{~K}_{33,8}+$ coлома + гичка (варіанти 11, 29, 47, 65) після всіх попередників забезпечило підвищення врожайності зерна пшениці озимої на 0,22-1,43 т/га порівняно $з$ контролем без добрив, без соломи, без гички (варіанти 9, 27, 45, 63). У сівозміні з чорним паром застосування за ротацію сівозміни 3 
розрахунку на 1 га ріллі 6,25 т гною + $\mathrm{N}_{33,8} \mathrm{P}_{45,0} \mathrm{~K}_{33,8}$ без соломи, без гички (варіант 46) сприяло зменшенню поширення кореневих гнилей пшениці озимої до рівня $22,0 \%$ із одночасним зниженням інтенсивності розвитку хвороби до величини 8,4 \% та підвищенню урожайності цієї культури до найбільшого показника - 6,32 т/га; тоді як за внесення за ротацію сівозміни з розрахунку на 1 га ріллі 6,25 т гною $+\mathrm{N}_{33,8} \mathrm{P}_{45,0} \mathrm{~K}_{33,8}+$ солома + гичка (варіант 47) поширення кореневих гнилей становило $24,2 \%$, інтенсивність їх розвитку - 9,6 \%, а урожайність пшениці склала 5,92 т/га.

Проведеними нами дослідженнями встановлено, що в просапній сівозміні, як за поверхневого обробітку грунту на глибину 10-12 см під зернові культури, в тім числі і під пшеницю озиму, так i за оранки під усі культури, на неудобреному фоні без добрив, без соломи, без гички (варіанти 21 і 27) і на фоні 6,25 т гною $+\mathrm{N}_{33,8} \mathrm{P}_{45,0} \mathrm{~K}_{33,8}$ без соломи, без гички (варіанти 22 і 28), ураження рослин пшениці озимої кореневими гнилями та інтенсивність їх розвитку відмічали майже на одному рівні: 16,4 і 15,6 \%, 15,8 і 15,3 \% - поширення хвороби та 6,3 і 6,0\%, 6,1 і 5,8 \%-інтен- сивність іiі розвитку відповідно (таблиця 2).

Поверхневий обробіток грунту на глибину 10 12 см під зернові культури, в тім числі і під пшеницю озиму, а також оранка під усі культури на фоні 6,25 т гною $+\mathrm{N}_{33,8} \mathrm{P}_{45,0} \mathrm{~K}_{33,8}+$ солома + гичка (варіанти 23 і 29) викликали суттєве збільшення ураження рослин пшениці кореневими гнилями до рівня 24,4 і 20,0 \% 3 одночасним підвищенням інтенсивності розвитку хвороби до величин 10,5 і 7,3 \% відповідно.

Слід відмітити, що як за проведення поверхневого обробітку грунту на глибину 10-12 см під зернові культури, в тім числі і під пшеницю озиму, так і за проведення оранки під усі культури, на фоні без добрив, без соломи, без гички (варіанти 21 і 27) в просапній сівозміні після такого попередника, як кукурудза на силос, одержали найнижчу врожайність зерна - 2,88 і 2,96 т/га відповідно. Проведення оранки під усі культури iз застосуванням за ротацію сівозміни на 1 га ріллі 6,25 т гною $+\mathrm{N}_{33,8} \mathrm{P}_{45,0} \mathrm{~K}_{33,8}+$ солома + гичка (варіант 29) забезпечило найвищу врожайність зерна пшениці озимої - 4,39 т/га.

\section{2. Ураженість пшениці озимої кореневими гнилями та ї̈ урожайність залежно від способів} основного обробімку трунту і внесення добрив у просапній сівозміні (в середньому за 2012-2016 рр.)

\begin{tabular}{|c|c|c|c|c|c|}
\hline \multirow{2}{*}{$\begin{array}{c}\text { Ba- } \\
\text { ріант }\end{array}$} & \multirow{2}{*}{$\begin{array}{c}\text { Спосіб основного } \\
\text { обробітку грунту } \\
\text { в сівозміні }\end{array}$} & \multirow{2}{*}{$\begin{array}{c}\text { Система удобрення за } \\
\text { ротацію сівозміни з } \\
\text { розрахунку на } 1 \text { га ріллі }\end{array}$} & \multicolumn{2}{|c|}{$\begin{array}{c}\text { Ураженість пшениці } \\
\text { озимої кореневими } \\
\text { гнилями }\end{array}$} & \multirow{2}{*}{$\begin{array}{l}\text { Урожайність } \\
\text { пшениці } \\
\text { озимої, т/га }\end{array}$} \\
\hline & & & $\begin{array}{c}\text { поши- } \\
\text { рення, \% }\end{array}$ & $\begin{array}{l}\text { інтенсив- } \\
\text { ність роз- } \\
\text { витку, \% } \\
\end{array}$ & \\
\hline \multicolumn{6}{|c|}{ Попередник кукурудза на силос } \\
\hline 21 & \multirow{3}{*}{$\begin{array}{c}\text { Поверхневий обро- } \\
\text { біток грунту на гли- } \\
\text { бину 10-12 см під } \\
\text { зернові культури, в } \\
\text { тім числі під пшени- } \\
\text { цю озиму }\end{array}$} & $\begin{array}{c}\text { Без добрив, без соломи, } \\
\text { без гички }\end{array}$ & 16,4 & 6,3 & 2,88 \\
\hline 22 & & $\begin{array}{c}\text { 6,25 т гною + } \\
+\mathrm{N}_{33,8} \mathrm{P}_{45,0} \mathrm{~K}_{33,8} \text { без } \\
\text { соломи, без гички }\end{array}$ & 15,8 & 6,1 & 3,91 \\
\hline 23 & & $\begin{array}{c}\text { 6,25 т гною }+ \\
\mathrm{N}_{33,8} \mathrm{P}_{45,0} \mathrm{~K}_{33,8}+\text { солома }+ \\
\text { гичка }\end{array}$ & 24,4 & 10,5 & 4,15 \\
\hline 27 & \multirow{3}{*}{$\begin{array}{c}\text { Оранка під усі куль- } \\
\text { тури }\end{array}$} & $\begin{array}{c}\text { Без добрив, без соломи, } \\
\text { без гички } \\
\end{array}$ & 15,6 & 6,0 & 2,96 \\
\hline 28 & & $\begin{array}{c}\text { 6,25 т гною + } \\
+\mathrm{N}_{33,8} \mathrm{P}_{45,0} \mathrm{~K}_{33,8} \text { без } \\
\text { соломи, без гички }\end{array}$ & 15,3 & 5,8 & 3,91 \\
\hline 29 & & $\begin{array}{c}\text { 6,25 т гною + } \\
\mathrm{N}_{33,8} \mathrm{P}_{45,0} \mathrm{~K}_{33,8}+\text { солома }+ \\
\text { гичка } \\
\end{array}$ & 20,0 & 7,3 & 4,39 \\
\hline \multicolumn{3}{|c|}{ HIP $_{05}$ загальна } & 1,9 & 0,6 & 0,19 \\
\hline \multirow{2}{*}{\multicolumn{3}{|c|}{$\frac{\text { HІР }_{05} \text { для ф-ра А (обробіток грунту) }}{\text { НІР }_{05} \text { для ф-ра В (удобрення) }}$}} & 1,1 & 0,3 & 0,10 \\
\hline & & & 1,4 & 0,4 & 0,14 \\
\hline
\end{tabular}




\section{3. Ураженість пшениці озимої кореневими гнилями та ӥ̈ урожайність залежно від способів основного обробітку грунту і внесення добрив у зернопросапній сівозміні \\ (в середньому за 2012-2016 рр.)}

\begin{tabular}{|c|c|c|c|c|c|}
\hline \multirow{2}{*}{$\begin{array}{c}\text { Ba- } \\
\text { ріант }\end{array}$} & \multirow{2}{*}{$\begin{array}{c}\text { Спосіб основного } \\
\text { обробітку грунту } \\
\text { в сівозміні }\end{array}$} & \multirow{2}{*}{$\begin{array}{c}\text { Система удобрення за } \\
\text { ротацію сівозміни в } \\
\text { розрахунку на } 1 \text { га ріллі }\end{array}$} & \multicolumn{2}{|c|}{$\begin{array}{c}\text { Ураженість пшениці } \\
\text { озимої кореневими } \\
\text { гнилями }\end{array}$} & \multirow{2}{*}{$\begin{array}{r}\text { Урожай- } \\
\text { ність ози- } \\
\text { мої пше- } \\
\text { ниці, т/га }\end{array}$} \\
\hline & & & $\begin{array}{c}\text { поши- } \\
\text { рення, \% }\end{array}$ & $\begin{array}{l}\text { інтенсивність } \\
\text { розвитку, \% }\end{array}$ & \\
\hline \multicolumn{6}{|c|}{ Попередник пшениця озима } \\
\hline 57 & \multirow{3}{*}{$\begin{array}{c}\text { Плоскорізний об- } \\
\text { робіток грунту під } \\
\text { усі культури, в тім } \\
\text { числі під пшеницю } \\
\text { озиму на глибину } \\
\text { 20-22 см }\end{array}$} & $\begin{array}{c}\text { Без добрив, без соломи, } \\
\text { без гички }\end{array}$ & 24,3 & 9,7 & 2,98 \\
\hline 58 & & $\begin{array}{c}\text { 6,25 т гною }+\mathrm{N}_{33,8} \mathrm{P}_{45,0} \mathrm{~K}_{33,8} \\
\text { без соломи, без гички }\end{array}$ & 26,9 & 11,1 & 4,11 \\
\hline 59 & & $\begin{array}{c}6,25 \text { т гною }+\mathrm{N}_{33,8} \mathrm{P}_{45,0} \mathrm{~K}_{33,8} \\
+ \text { солома }+ \text { гичка }\end{array}$ & 32,0 & 12,6 & 4,21 \\
\hline 63 & \multirow{3}{*}{$\begin{array}{l}\text { Оранка під усі } \\
\text { культури }\end{array}$} & $\begin{array}{c}\text { Без добрив, без соломи, } \\
\text { без гички } \\
\end{array}$ & 23,5 & 9,5 & 3,04 \\
\hline 64 & & $\begin{array}{c}6,25 \text { т гною }++\mathrm{N}_{33,8} \mathrm{P}_{45,0} \mathrm{~K}_{33,8} \\
\text { без соломи, без гички } \\
\end{array}$ & 27,2 & 11,5 & 4,13 \\
\hline 65 & & $\begin{array}{c}6,25 \text { т гною }+\mathrm{N}_{33,8} \mathrm{P}_{45,0} \mathrm{~K}_{33,8} \\
+ \text { + солома + гичка } \\
\end{array}$ & 33,4 & 12,9 & 4,25 \\
\hline 69 & \multirow{3}{*}{$\begin{array}{c}\text { Комбінований об- } \\
\text { робіток грунту } \\
\text { (оранка під цукро- } \\
\text { ві буряки, плоско- } \\
\text { різний обробіток } \\
\text { під зернові куль- } \\
\text { тури, в тім числі } \\
\text { під пшеницю ози- } \\
\text { му на 20-22 см) }\end{array}$} & $\begin{array}{c}\text { Без добрив, без соломи, } \\
\text { без гички }\end{array}$ & 22,9 & 9,5 & 3,12 \\
\hline 70 & & $\begin{array}{c}6,25 \text { т гною }+\mathrm{N}_{33,8} \mathrm{P}_{45,0} \mathrm{~K}_{33,8} \\
\text { без соломи, без гички } \\
\end{array}$ & 27,0 & 11,2 & 4,08 \\
\hline 71 & & $\begin{array}{c}6,25 \text { т гною }+\mathrm{N}_{33,8} \mathrm{P}_{45,0} \mathrm{~K}_{33,8} \\
+ \text { солома }+ \text { гичка }\end{array}$ & 33,7 & 13,1 & 4,19 \\
\hline \multicolumn{3}{|c|}{ HIP $_{05}$ загальна } & 2,3 & 0,7 & 0,20 \\
\hline \multicolumn{3}{|c|}{ НІР $_{05}$ для ф-ра А (обробіток грунту) } & 1,4 & 0,4 & 0,12 \\
\hline \multicolumn{3}{|c|}{$\mathrm{HIP}_{05}$ для ф-ра В (удобрення) } & 1,3 & 0,4 & 0,11 \\
\hline
\end{tabular}

Нашими п'ятирічними дослідженнями також встановлено, що в зернопросапній сівозміні після такого попередника як пшениця озима, у разі проведення плоскорізного обробітку грунту під усі культури, в тім числі й під наступну пшеницю озиму, на глибину 20-22 см, оранки під усі культури і комбінованого обробітку грунту (оранка під цукрові буряки на глибину 30-32 см, плоскорізний обробіток під зернові культури, в тім числі й під пшеницю озиму на глибину 20-22 см) на неудобреному фоні без добрив, без соломи, без гички (варіанти 57, 63, 69) викликало ураження рослин пшениці озимої кореневими гнилями майже на одному рівні: 24,$3 ; 23,5$ i $22,9 \%$ - поширення хвороби та 9,7; 9,5 і 9,5\% інтенсивність її розвитку відповідно (таблиця 3).

Слід зауважити, що за проведення різних способів основного обробітку грунту, що поєдну- ються із внесенням за ротацію сівозміни з розрахунку на 1 га ріллі 6,25 т гною $+\mathrm{N}_{33,8} \mathrm{P}_{45,0} \mathrm{~K}_{33,8}$ без соломи, без гички (варіанти $58,64,70$ ) і 6,25 т гною $+\mathrm{N}_{33,8} \mathrm{P}_{45,0} \mathrm{~K}_{33,8}+$ солома + гичка (варіанти $59,65,71)$, спостерігали суттєве збільшення поширення кореневих гнилей рослин пшениці озимої до рівня 26,$9 ; 27,2 ; 27,0 \%$ і 32,$0 ; 33,4 ; 33,7 \%$ відповідно з підвищенням інтенсивності розвитку хвороби до величин 11,$1 ; 11,5 ; 11,2 \%$ і 12,6 ; 12,$9 ; 13,1 \%$ відповідно. Крім того, за проведення в сівозміні під усі культури плоскорізного обробітку або оранки чи комбінованого обробітку грунту на всіх удобрених фонах відмічали збільшення ураження рослин пшениці озимої кореневими гнилями; при цьому за різних способів основного обробітку грунту ураження рослин пшениці хворобою виявилось на одному рівні. 


\section{СІЛЬСЬКЕ ГОСПОДАРСТВО. РОСЛИННИЦТВО}

За проведення різних способів основного обробітку грунту в сівозміні на неудобреному фоні без добрив, без соломи і без гички (варіанти 57, $63,69)$, урожайність пшениці озимої виявилася за всі роки досліджень найнижчою - 2,98; 3,04; 3,12 т/га відповідно. Проведення плоскорізного обробітку грунту під усі культури чи оранки або комбінованого обробітку грунту за внесення за ротацію сівозміни з розрахунку на 1 га ріллі 6,25 т гною $+\mathrm{N}_{33,8} \mathrm{P}_{45,0} \mathrm{~K}_{33,8}$ без соломи, без гички (варіанти $58,64,70)$ і 6,25 т гною $+\mathrm{N}_{33,8} \mathrm{P}_{45,0} \mathrm{~K}_{33,8}+$ солома + гичка (варіанти $59,65,71$ ) забезпечило істотне підвищення врожайності зерна пшениці озимої до рівнів 4,$11 ; 4,13 ; 4,08$ т/га та 4,21; 4,25; 4,19 т/га відповідно.

\section{Висновки:}

1. Найбільшим ураження рослин пшениці озимої кореневими гнилями виявилось в зернопросапній сівозміні, де попередником була пшениця, а також у зернопаропросапній сівозміні, де попередником був чорний пар. На ділянках цих варіантів було уражено хворобою, в середньому за п'ять років, 23,5-33,4 \% та 22,0-26,4 \% рослин пшениці, а інтенсивність розвитку хвороби тут становила 9,5-12,9\% та 8,4-10,2\% відповідно. Найменше уражених кореневими гнилями рослин пшениці озимої $(15,3-20,0 \%)$ за найнижчої інтенсивності розвитку хвороби (5,8-7,3 \%) відмічали за роки досліджень у посівах після кукурудзи на силос. У сівозміні з чорним паром внесення за ротацію з розрахунку на 1 га ріллі 6,25 т гною $+\mathrm{N}_{33,8} \mathrm{P}_{45,0} \mathrm{~K}_{33,8}$ без соломи, без гички сприяло зменшенню поширення кореневих гнилей пшениці озимої до рівня $22,0 \%$ із одночасним зниженням інтенсивності розвитку хвороби до величини $8,4 \%$ та підвищення урожайності культури до найбільшого показника за роки екс-

\section{БІБЛІОГРАФІЯ}

1. Доспехов Б. А. Методика полевого опыта с основами статистической обработки результатов исследований: [монография] / Б. А. Доспехов. М.: Колос, 1979. - $416 \mathrm{c}$.

2. Кориунова А. Ф. Защита пшеницы от корневых гнилей / А. Ф. Коршунова. Изд. 2-е, перераб. и доп. - Л. : Колос (Ленинград. отд-ние), 1976. - С. 10-29.

3. Методика исследований сахарной свеклы [методические рекомендации] / [Зубенко В. Ф., Борисюк В. А., Балков И. Я и д.р.]; под. ред. В.Ф. Зубенко. - К. : ВНИС, 1986. - 292 с.

4. Олейніков $C$. С. Поширення та розвиток основних хвороб пшениці озимої / Є. С. Олейніков // Вісник Центру наукового забезпечення агро- перименту; тоді як внесення за ротацію сівозміни 3 розрахунку на 1 га ріллі 6,25 т гною + $\mathrm{N}_{33,8} \mathrm{P}_{45,0} \mathrm{~K}_{33,8}+$ солома + гичка призвело до поширення кореневих гнилей до рівня $24,2 \%$, інтенсивність їх розвитку становила $9,6 \%$, а урожайність пшениці озимої склала 5,92 т/га.

2. Проведення поверхневого обробітку грунту на глибину 10-12 см під зернові культури, в тім числі й під пшеницю озиму, на фоні 6,25 т гною $+\mathrm{N}_{33,8} \mathrm{P}_{45,0} \mathrm{~K}_{33,8}+$ солома + гичка в просапній сівозміні після кукурудзи на силос спричинило найбільше ураження рослин пшениці кореневими гнилями $(24,4 \%)$ з підвищенням інтенсивності розвитку хвороби до величини 10,5\%. Проведення оранки під усі культури в просапній сівозміні за внесення за ротацію сівозміни з розрахунку на 1 га ріллі 6,25 т гною $+\mathrm{N}_{33,8} \mathrm{P}_{45,0} \mathrm{~K}_{33,8}$ + солома + гичка забезпечило найвищу урожайність зерна пшениці озимої - 4,39 т/га.

3. У зернопросапній сівозміні після пшениці озимої, що виступала у якості попередника, за проведення плоскорізного обробітку, оранки i комбінованого обробітку грунту під усі культури на удобрених фонах відмічали суттєве збільшення ураження рослин пшениці кореневими гнилями порівняно із неудобреним фоном без добрив, без соломи, без гички; при цьому за різних способів основного обробітку грунту ураження рослин пшениці озимої хворобою було майже на одному рівні. Плоскорізний обробіток грунту, оранка і комбінований обробіток грунту в зернопросапній сівозміні за внесення за ротацію сівозміни із розрахунку на 1 га ріллі 6,25 т гною + $\mathrm{N}_{33,8} \mathrm{P}_{45,0} \mathrm{~K}_{33,8}$ без соломи, без гички і 6,25 т гною $+\mathrm{N}_{33,8} \mathrm{P}_{45,0} \mathrm{~K}_{33,8}+$ солома + гичка забезпечили істотне підвищення врожайності зерна культури.

промислового виробництва Харківської області. - 2012. - №13. - C. 32-34.

5. Пересыпкин В. Ф. Сельскохозяйственная фитопатология. 3-е изд., перераб. и доп./ В. Ф. Пересыпкин. - М. : Колос, 1982. - С. 49-51.

6. Ретьман С. В. Плямистості пшениці в Лісостепу України й концептуальні основи захисту: автореф. дис. на зд. наук. ст. доктора с.-г. наук: спец. 06.01.11 - «Фітопатологія» / С. В. Ретьман. - К., 2009. - 43 с.

7. Федоренко В. П. Чотири основоположних принципи / В. П. Федоренко, С. В. Ретьман // Захист і карантин рослин. - 2004. - № 1. - С. 3 5. 


\section{ANNOTATION}

Tyshchenko M. V., Smirnykh V. M., Filonenko S. V., Liashenko V. V. Defeat of winter wheat plants in root rot, depending on agrotechnical measures.

As a result of field studies, the effect of predecessors, fertilizer systems and methods of basic tillage on the damage of winter wheat plants by root rot in short-rotation crop rotations in the zone of inadequate moisture was established. The most affected wheat plants of winter rot was found in grain sown crop rotation, where the forerunner was the wheat itself, as well as in the grain-para-breeding crop rotation, where the black pairs were the precursor. The least affected by root rot of winter wheat plants $(15.3-20.0 \%)$ at the lowest intensity of disease (5.8-7.3\%) was observed after corn silage.
Conducting surface cultivation of soil at a depth of 10-12 cm under grain crops, including under winter wheat, against the background of $6.25 \mathrm{t}$ of manure $+\mathrm{N}_{33.8} \mathrm{R}_{45.0} \mathrm{~K}_{33.8}+$ straw + gill in the crop rotation after corn on silage caused most defeat of wheat plants by root rot $(24.4 \%)$ with an increase in the intensity of the disease to a value of $10.5 \%$. Providing plowing for all crops in the fertile crop rotation for rotation of crop rotation per hectare of arable land of 6.25 tons of manure $+\mathrm{N}_{33.8} \mathrm{R}_{45.0} \mathrm{~K}_{33.8}+$ straw + lace ensured the highest yield of wheat of winter wheat -4.39 tons/ha.

Key words: winter wheat, root rot, soil tillage, crop rotation, fertilizer system, distribution of disease, plant damage. 